\title{
Blue-White Variant of Basal Cell Carcinoma As a Mimicker of Melanoma: Dermoscopic Analysis
}

\section{Bir Melanoma Taklitçisi Olarak Mavi-Beyaz Varyant Bazal Hücreli Karsinoma: Dermoskopik Analiz}

Omer Faruk Elmas

Ahi Evran University, Faculty of Medicine, Department of Dermatology and

Veneorology, Kirsehir

Geliş Tarihi/Received: 7 November 2018 Kabul Tarihi/Accepted: 22 October 2018

Address correspondence to: Omer Faruk Ahi Evran University, Faculty of Medicine, Department of Dermatology and Veneorology, Kirsehir, Turkey

e-mail: dromerfarukelmas@gmail.com

ORCID

Omer Faruk Elmas

https://orcid.org/0000-0002-5474-6508

\begin{abstract}
Öz
Amaç: Bazal hücreli karsinomanın dermoskopik özellikleri iyi bilinmekle beraber, mavi beyaz varyant bazal hücreli karsinoma yakın zamanda tanımlanmış ve melanomayı taklit eden yönüne vurgu yapılmıştır. Bilgilerimize göre, literatürde bu özel varyant ile ilgili tek bir orjinal araştırma mevcuttur. Biz burada, bazal hücreli karsinomanın bu özel varyantını; klinik, dermoskopik ve histopatolojik yönüyle incelemeyi amaçladık.

Hastalar ve Yöntem: Çalışmamızda, iki farklı merkezde 2015-2018 yılları arasında histopatolojik olarak bazal hücreli karsinoma tanısı alan vakalar retrospektif olarak incelenmiştir. Dermoskopik olarak diffüz mavi beyaz alanlar ile prezente olan olgular çalışmaya dahil edilmiştir. Tüm olguların klinik, histopatolojik, demografik ve dermoskopik özellikleri dokümante edilmiştir.

Bulgular: Çalışmamızda toplamda 154 adet histopatolojik olarak doğrulanmış bazal hücreli karsinoma vakası gözden geçirilmiş ve bu vakalardan 15 'inin (\% 9.74) diffüz mavi beyaz dermoskopik patern ile prezente olduğu saptanmıştır. Vakaların tümü baş bölgesinde lokalizeydi. Tüm vakalarda histolojik inceleme, melanoma ve bazal hücreli karsinoma olmak üzere iki temel ön tanı ile yapılmıştı. Diffüz mavi beyaz alanlardan sonra en sık rastlanan dermoskopik bulgular sırasıyla irregüler serpentin damarlar (\% 60), periferal akça ağaç yaprağı benzeri alanlar (\% 46.6) ve ülserasyondu (\% 46.6). Tüm olguların histopatolojik incelemesi nodüler ya da nodüloülseratif bazal hücreli karsinoma olarak raporlanmıştı.

Sonuç: Çalışmamız, bilgilerimize göre, mavi beyaz varyant bazal hücreli karsinoma ile ilgili literatürdeki en geniş kapsamlı çalışma olma özelliğini taşımaktadır. Bu özel varyant, bazal hücreli karsinomanın oldukça sıradışı ve tanısı güç bir prezentasyonudur. Ayırıcı tanıda en önemli antite, melanomadır. Dermoskopik olarak diffüz mavi beyaz alanlar gösteren lezyonlarda bazal hücreli karsinomanın bu varyantı göz önüne alınmalıdır. Bazal hücreli karsinomaya spesifik dermoskopik ipuçlarının saptanması açısından dikkatli bir dermoskopik muayene, eksizyon öncesi diagnostik sürecin daha iyi yönlendirimesine katkı sağlayabilir
\end{abstract}

Anahtar Kelimeler: Bazal hücreli karsinoma, dermoskopi, mavi beyaz

\section{Abstract}

Aim: Dermoscopic features of basal cell carcinoma (BCC) have been well described in the literature, however, blue white variant of BCC has recently been described as a mimicker of melanoma. When reviewing the literature, it seems that there is just one original research about this special type of BCC. Here we aimed to evaluate this special and challenging variant of BCC cases of two dermatology departments from different regions of Turkey.

Patients and Methods: Dermoscopic images of the histopathologically approved BCC cases from two centers between the years 2015-2018 were reviewed. The cases showing diffuse blue white areas on dermoscopy were included in the study. The clinical and histopathological features, dermoscopic images and demographic data of all the cases were evaluated

Results: We detected $15(9.74 \%)$ lesions of BCC with diffuse blue-white dermoscopic pattern from 15 different patients among 154 cases of histopathologically confirmed basal cell carcinomas. All of the cases were located on the head region. All of the cases were excised with two main differantials: melanoma and BCC. The most common findings after blue white diffuse areas were irregular serpentine vessels $(60.0 \%)$, peripheral maple leaf like areas $(46.6 \%)$ and ulceration $(46.6 \%)$. The histopathological examination of all the cases were in keeping with nodular or noduloulcerative subtypes.

Conclusion: The present study, to the best of our knowledge, is the most comprehensive study regarding this rare and challenging presentation of BCC. The main differential diagnosis is melanoma. We suggest that it would be logical to consider blue white BCC in the lesions showing diffuse blue-white color. A careful dermoscopic examination regarding the presence of specific dermoscopic clues to basal cell carcinoma can provide a well-directed preliminary diagnostic evaluation.

Key words: Basal cell carcinoma, blue white, dermoscopy

\section{INTRODUCTION}

Basal cell carcinoma (BCC) is a malignant epithelial skin tumor considered to be the most common type of skin cancer. It is also the most common cancer in the world. Incidence of the disease is continuing to increase and this increasing is associated with significant morbidity (1). Many clinicopathologic subtypes of BCC like nodular (with micronodular), infiltrative (with morphoeic), superficial and mixed subtypes have been described (2).
Cite this article as: Elmas OF. Blue-White Variant of Basal Cell Carcinoma As a Mimicker of Melanoma: Dermoscopic Analysis. Selcuk Med J 2019;35(2): 85-89
Disclosure: Author has not a financial interest in any of the products, devices, or drugs mentioned in this article. The research was not sponsored by an outside organization. Author has agreed to allow full access to the primary data and to allow the journal to review the data if requested. 
Dermoscopy is a widely used non invasive diagnostic tool in the diagnosis of many dermatological conditions. It is increasingly using for both pigmented and non pigmented skin lesions including inflammatory dermatosis (4).

Dermoscopic features of BCC have also been well described in the literature. Blue-ovoid nests, arborizing vessels, maple leaf like structures, brown grey dots/ globules, spoke-wheel like areas, and ulceration are the main dermoscopic findings of BCC (5).

Blue white variant of $B C C$ has firstly been described by Felder et al (6) in a case of 76 years old female patient who presented with two nodular lesions on the left anterior lower leg. The lesions showed "diffuse white blue areas" on dermoscopic examination were excised to exclude melanoma and histopathological diagnosis of nodular BCC was approved.

In the present study, we evaluated the blue white variant of BCC cases of two dermatology departments from different regions of Turkey.

\section{PATIENTS AND METHODS}

The study was conducted at dermatology departments of Ahi Evran University and Kars State Hospital. Dermoscopic images of 154 cases with histopathologically approved BCC between the years 2015-2018 were reviewed. The cases which show diffuse blue white areas on dermoscopy were included in the study. The clinical and histopathological features, dermoscopic images (Dermlite pro $\mathrm{hr}$ ii and Dermlite DL 4, San Juan Capistrano California, USA) and demographic data of all the cases were evaluated. The study is approved by the local clinical research ethic comittee. Descriptive statistics were made for analysis of the collected data.

\section{RESULTS}

We detected $15(9.74 \%)$ lesions of BCC with diffuse blue-white dermoscopic pattern from 15 different patients among 154 cases of histopathologically confirmed basal cell carcinomas.

The mean age was $64 \pm 12$. 10 patients $(66.6 \%)$ were male and $5(33.3 \%)$ patients were female. All of the cases were located on the head region. The mean size of the lesions was $2.1 \pm 3.2 \mathrm{~cm}$. The demographic, clinical and histopathological characteristics of the cases are summarized in Table 1.

All of the cases were excised with two main differantials: melanoma and BCC.

The main dermoscopic feature was diffuse white blue structureless areas seen in all the lesions (Figure 1-6). The other dermoscopic features detected were peripheral maple leaf like areas, white lines, white globules, black globules, peripheral multiple grey and brown dots, large diameter vessels, arborasing vessels, irregular serpentine vessels, hair pin vessels, dotted vessels, ulceration, scale and crust (Figure 1-6). The most common findings after blue white diffuse areas were irregular serpentine vessels (60.0 $\%$ ), peripheral maple leaf like areas (46.6\%) and ulceration (46.6\%). Dermoscopic findings of all the cases are shown in Table 2.

When coming to the histopathology, all of the cases were in keeping with nodular or noduloulcerative subtypes. The sections of all cases showed typical findings of nodular basal cell carcinoma like nodular blue islands of tumor cells, peripheral palisading, retraction artifact, fibromyxoid stroma in different

Table 1. Clinical and histological findings of the cases.

\begin{tabular}{llllll}
\hline Case & Sex & Age & Site & Morphology & Histopathology \\
\hline 1 & $\mathrm{M}$ & 54 & Nose & Black nodule, $1 \times 0.5 \mathrm{~cm}$ & Nodular \\
2 & $\mathrm{M}$ & 62 & Nose & Blue papule 0,8x0,6 cm & Noduloulcerative \\
3 & $\mathrm{M}$ & 48 & Cheek & Brown-Blue papule $0.7 \times 0.7 \mathrm{~cm}$ & Nodular \\
4 & $\mathrm{M}$ & 60 & Chin & Black Nodule $0.5 \times 0.6 \mathrm{~cm}$ & Nodular \\
5 & $\mathrm{M}$ & 82 & Forehead & Black Nodule $1 \times 1,5 \mathrm{~cm}$ & Nodular \\
6,7 & $\mathrm{M}$ & 88 & Cheek & Grey black papule $0.8 \times 0.6 \mathrm{~cm}$ and black papule $0.5 \times 0.6 \mathrm{~cm}$ \\
8 & $\mathrm{M}$ & 72 & Nose & Grey black papule $1 \times 0.8 \mathrm{~cm}$ & Noduloulcerative \\
9 & $\mathrm{M}$ & 62 & Cheek & Grey plaque $2 \times 1,8 \mathrm{~cm}$ & Noduloulcerative \\
10 & $\mathrm{~F}$ & 76 & Temple & Black-red nodule $4 \times 3 \mathrm{~cm}$ & Noduloulcerative \\
11 & $\mathrm{M}$ & 66 & Temple & Grey-black plaque $2,5 \times 2 \mathrm{~cm}$ & Noduloulcerative \\
12 & $\mathrm{~F}$ & 69 & Nasolabial sulcus & Grey black papule $1 \times 0.8 \mathrm{~cm}$ & Nodular \\
13 & $\mathrm{~F}$ & 47 & Infraorbital & Grey nodule $1,4 \times 0.8 \mathrm{~cm}$ & Noduloulcerative \\
14 & $\mathrm{~F}$ & 58 & Forehead & Blue-grey plaque $1 \times 1 \mathrm{~cm}$ & Nodular \\
15 & $\mathrm{~F}$ & 52 & Infraorbital & Blue nodule $0.4 \times 0.25 \mathrm{~cm}$ & \\
\hline
\end{tabular}




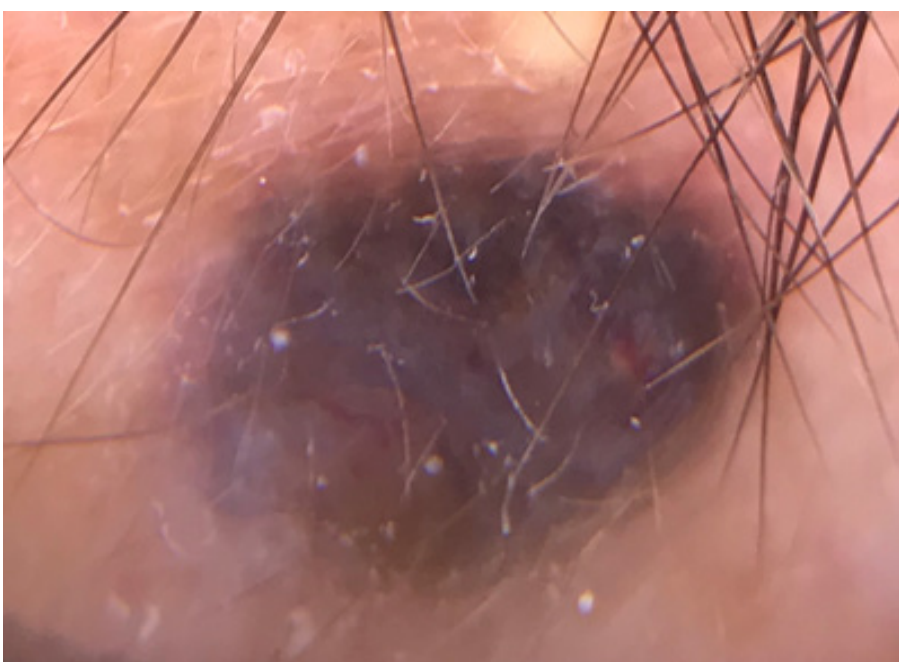

Figure 1. Diffuse blue white area, irregular serpentine vessels

combination (Figure 6, 7).

\section{DISCUSSION}

There are very few studies about blue white variant of BCC and it is first reported by Felder et al. (6) in context of a case. Except this case study, there is just one study in the literature in which Turkmen et al reported 8 cases of blue white variant BCC (7). To the best of our knowledge, here we present the largest series of blue white variant BCC. Turkmen et al de-scribed blue white variant BCC as presence of diffuse blue-white color nearly in the whole lesion. In the study of Turkmen et al. (7), the ratio of blue white variant $B C C$ to all $B C C$ was $2.3 \%$. In our study, this ratio was $9.8 \%$. In the study of Turkmen et al. (7), 5 of 8 lesions were located on the head region. Back, arm

Table 2. Dermoscopic findings of the cases.

\begin{tabular}{|c|c|c|}
\hline Dermoscopic finding & $\operatorname{ases}(n=15)$ & Percent \\
\hline Diffuse white blue structureless areas & 15 & $100 \%$ \\
\hline Large diameter vessels & 3 & $20.0 \%$ \\
\hline White lines & 5 & $33.3 \%$ \\
\hline Black globules & 5 & $33.3 \%$ \\
\hline Peripheral maple leaf like areas & 7 & $46.6 \%$ \\
\hline Arborizing vessels & 4 & $26.6 \%$ \\
\hline Irregular serpentine vessels & 9 & $60.0 \%$ \\
\hline White globules & 4 & $26.6 \%$ \\
\hline Peripheral multiple grey and brown dots & 4 & $26.6 \%$ \\
\hline Ulceration & 7 & $46.6 \%$ \\
\hline Scale & 6 & $40.0 \%$ \\
\hline Crust & 5 & $33.3 \%$ \\
\hline Hair pin vessels & 6 & $40.0 \%$ \\
\hline Dotted vessels & 5 & $33.3 \%$ \\
\hline
\end{tabular}

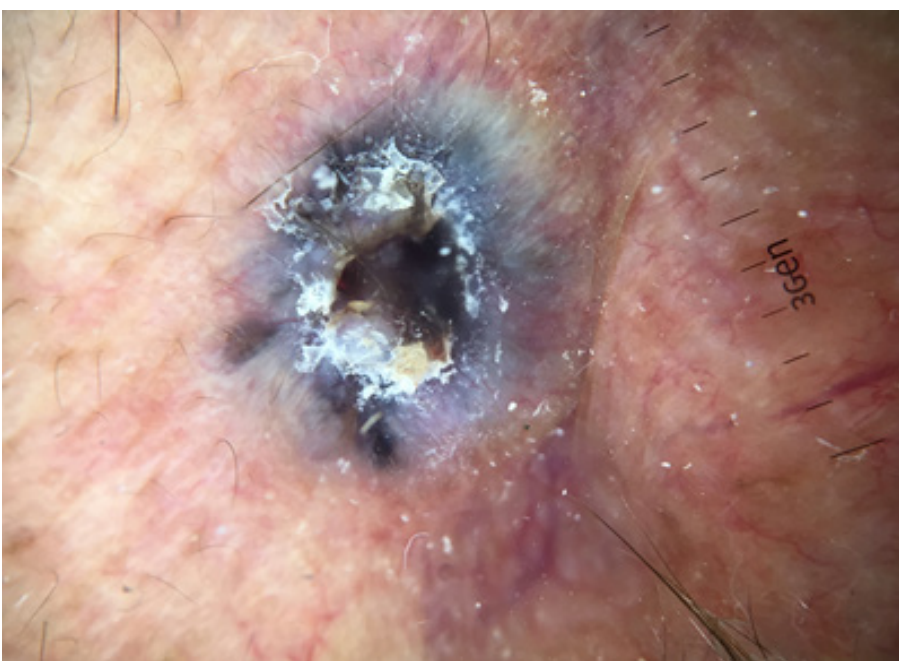

Figure 2. Diffuse blue white area, peripheral maple leaf like areas, black globules, irregular serpentine vessels, white globules, ulceration, scale and crust findings are visible.

and hand were other localizations for the remaining 3 cases. In the present study, all of the lesions were located on the head region.

Altough histopathological examination remains as a gold standart in diagnosis of the tumoral lesions, dermoscopic features of BCC are well described and most of the cases can easily be diagnosed by dermoscopy with presence of some typical features like maple leaf like struc-tures, blue ovoid nests, spoke



Figure 3. Diffuse blue white area, large diameter vessels, white lines, peripheral maple leaf like areas 


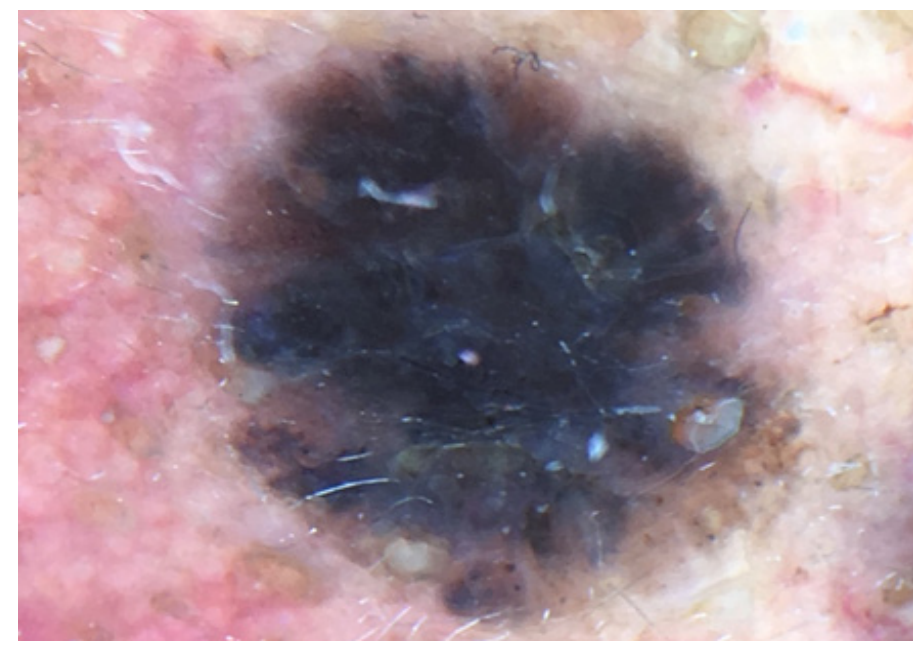

Figure 4. Diffuse blue white area, peripheral maple leaf like areas

wheel like structures, arborising vessels. But in some cases it can be hard to make a reliable evaluation with dermoscopy even for an experienced dermoscopist. Blue white structures or "blue white weil" can be rarely seen in BCC cases and it is usually considered one of the main clues to melanoma. So, we believe that blue white variant of $B C C$ is one of the most challenging aspect of BCC and it can be easily confused with melanoma clinically and dermoscopically. In our study, we found that most of the blue white variant BCC cases had also at least one characteristic feature of BCC

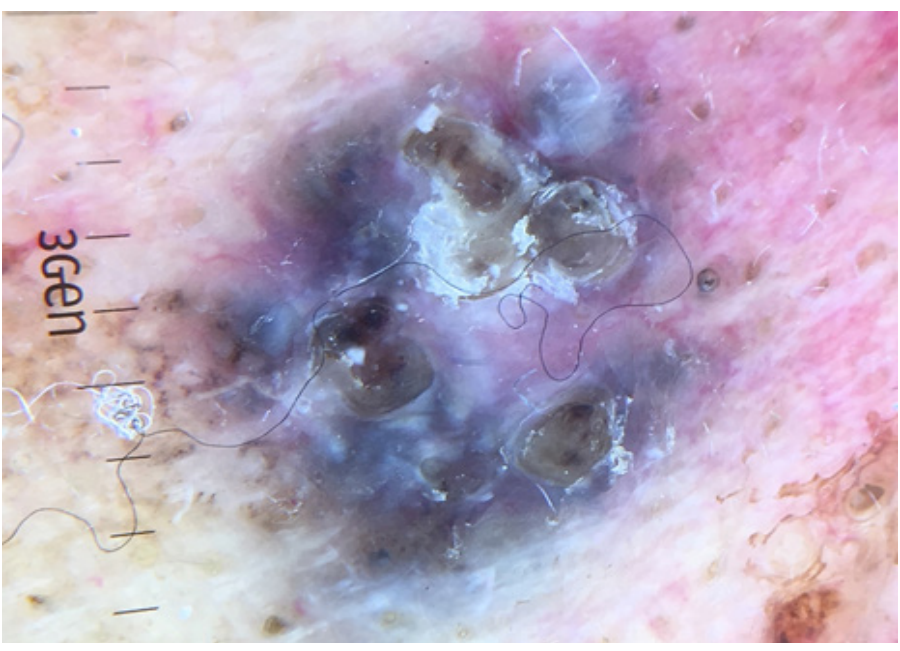

Figure 5. Diffuse blue white area, irregular serpentine vessels, white globules, peripheral multiple grey and brown dots, ulceration, scale and crust.

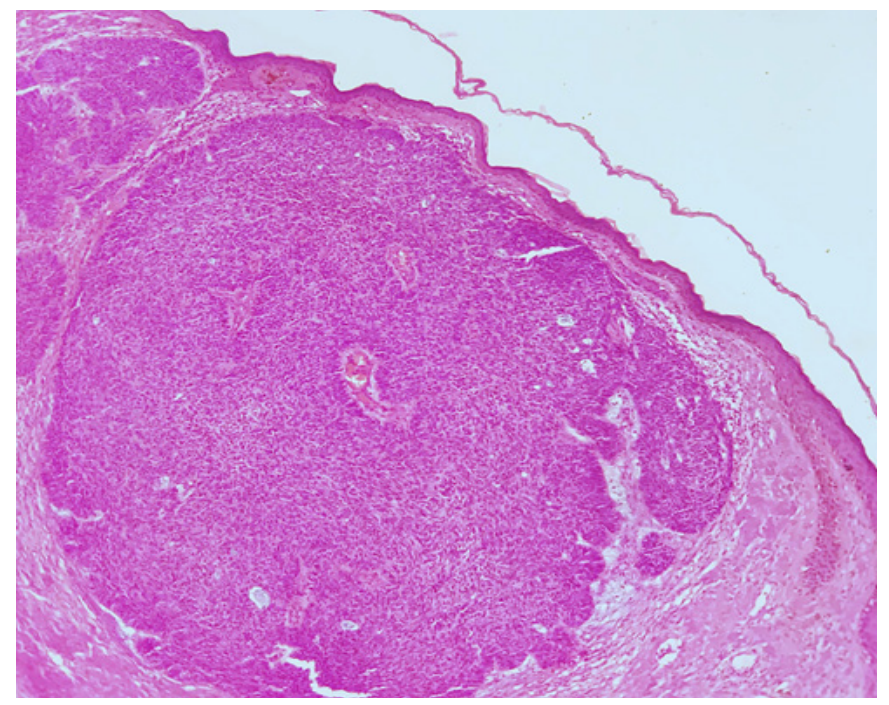

Figure 6. Diffuse blue white area, nodular blue island of tumor cells, peripheral palisading, retraction artifact, fibromyxoid stroma and superficial dermal pigmented melanophages (x10, h\&E)

like peripheral maple leaf like structures (46.6\%), ulceration (46.6\%), peripheral multiple grey brown dots $(26.6 \%)$, arborising vessels $(20 \%)$ and large diameter vessels (20\%). Three cases, however, didn't have any considerable clue to BCC. Especially in these 3 cases dermoscopy had limited value to make a reliable preoperative differential diagnosis between

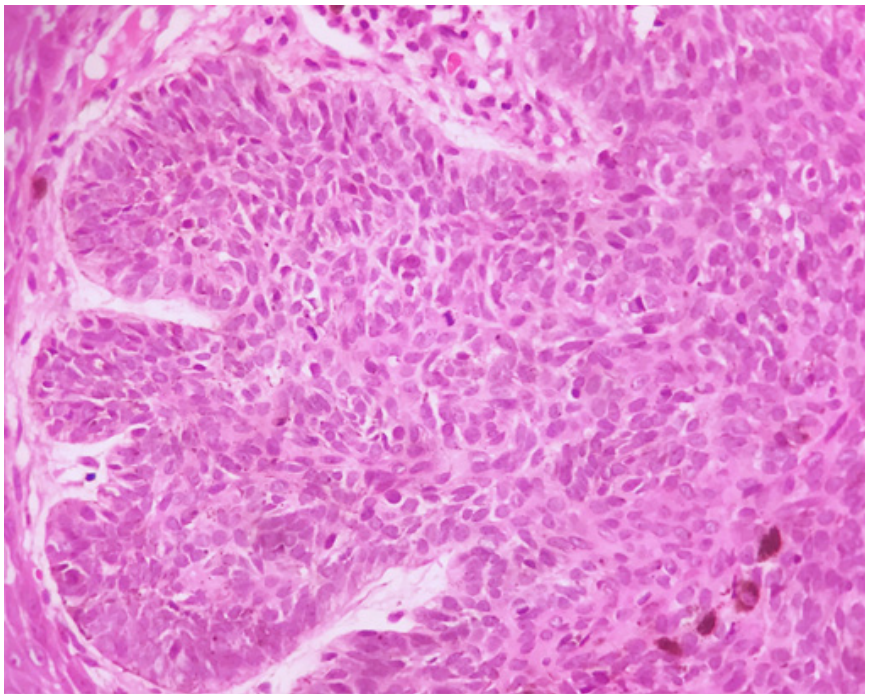

Figure 7. Fibromyxoid stroma, retraction artifact, atypia, mitosis and deep pigmented melanophages located in the tumor island and stroma can be seen clearly. (X40, H\&E) 
BCC and melanoma. In the study of Turkmen et al. (7), all the cases showed at least one characteristic feature of BCC. These features were ulceration $(75 \%)$, arborising vessels $(50 \%)$, large diameter vessels (37.5\%), peripheral maple like structure (one case). Felder et al. (6) also reported focal ulcerations and arborizing vessels as the concomitant features of the diffuse blue white areas.

In this context, we believe that it would be logical to look for the relatively specific tips men-tioned above for BCC in lesions characterized by diffuse blue and white areas.

When coming to the histopathology, in the present study, all of the cases reported as pig-mented nodular $(46.6 \%)$ or pigmented noduloulcerative $(53.3 \%)$ basal cell carcinoma. In the study of Turkmen et al. (7), the histopathological subtypes of the cases were similarly nodular or noduloulcerative. Histopathological sections of all the cases showed widely distrubited superficial and deep pigmented melanophages in the tumor islands and stroma. We think that this histological finding is correlated with the diffuse blue and white color. Turkmen et al had also same opinion in this regard.

Consequently, it can be said that the blue white variant, as a strong imitator of melanoma, is a rare and challenging presentation of BCC. In this regard, we think that it would be logical to consider blue white $\mathrm{BCC}$ in the lesions showing diffuse blue-white color.

Conflict of interest: Author declares that there is no conflict of interest between the authors of the article.

Financial conflict of interest: Author declares that he did not receive any financial support in this study.

Address correspondence to: Omer Faruk Elmas, Ahi Evran University, Faculty of Medicine, Department of Dermatology and Veneorology, Kirsehir, Turkey

e-mail: dromerfarukelmas@gmail.com

Phone Mobile: 905330260679

\section{REFERENCES}

1. Cameron MC, Lee E, Hibler B, et al. Basal cell carcinoma: Contemporary approaches to diagnosis, treatment, and prevention. J Am Acad Dermatol 2019;80(2):321-339.

2. Wysocka MM, Dmochowska MB, Węklar DS, et al. Basal cell carcinoma-diagnosis. Contemp Oncol (Pozn) 2013; 17(4): 337-42.

3. Wozniak-Rito A, Zalaudek I, Rudnicka L. Dermoscopy of basal cell carcinoma. Exp Dermatol 2018;43(3):241-7.

4. Errichetti E, Stinco G. Dermoscopy in general dermatology: A practical overview. Der-matol ther (Heidelb) 2016;6(4):471507.

5. Verduzco-Martínez AP, Quinones-Venegas R, GuevaraGutierrez E, et al. Correlation of dermoscopic findings with histopathologic variants of basal cell carcinoma. Int $\mathrm{J}$ Dermatol 2013;52(6):718e21.

6. Felder S, Rabinovitz H, Oliviero M, et al. Dermoscopic pattern of pigmented basal cell carcinoma, blue-white variant. Dermatol Surg 2006;32(4):569e70.

7. Turkmen M, Gerceker Turk B, Karaarslan IK, et al. Blue-white variant of pigmented basal cell carcinoma. Dermatologica Sinica (2018), https:// doi.org/10.1016/j.dsi.2018.05.003 (in press) 